24 プロジェクタ用光源に適した

$$
\text { メタルハライドランプについての一考察 }
$$

川島弘道

田中以知 郎

本旧和椎

(東芝ライテック株式会补)

1.はじめに

近年、大画面ディスプレイ装固への関心が急速に高まっている中、小形・軽量性の面か ら、液晶パネルをライトバルフとして用いたプロジェク夕（液晶プロジェク夕）が注目を 集め、製品化が進んでいる。これに伴い、プロジェクタに用いられる投射用光源も、メ夕 ルハライドランプを中心に開発・改良が活発に行れ机てる。この光源に要求される特性 として、（1）高効事・高集光事，（2）色再現性（色純度），(3）長寿命，(4) 㮩再点奵 性,などがあるが、ここでは、寿命特性と色再現性を巾心に検討した結果について垠告 する。

\title{
2. 封入物の検討
}

\section{2-1) 照度䧽持事の改善}

現在、液晶プロジェク夕用光源として用いられて いるメタルハライドランプの封入物は、希土類金属 を主体とした沃化物系(DJ-Nd-Cs-I系等) が、主流 である。これら封入物を用いたランプでは、点灯中 に発光管材料である石英が比较的早期に失透し、ア 一ク輝度およびリフレク夕の集光率の低下を促進さ せる。そのため、スクリーン面の照度維持事低下が 早いという開題がある。そこで我々は、沃化物系に 比へ、石英との反応が比的少ないと考えられる具 化物系封入物について検討し、評侕した。その結果、 因1に示すような点奵中のスクリーン面の照度低下 を大幅に改善できることが確認できた。

2-2)色再現性の改善

一方、臭化物系封入物を用いると、H g インの発 光が強くなるため、色再現性が悪化するが、これに ついては、In・T片ハロゲン化物を添加すること により啁決できることを確認した。（图 $2 ， 3$ 参照）

\section{3. まとぬ}

波晶プロジェク夕用光源として用いられるメタル 八ライドランプの封入物を中心に検討した結果、寿 命特性・色再現性改善の可能性を確認できた。

\section{4. 参考文献}

・「液晶ビデオプロジェク夕技術」闌トリケップス

・「フラットパネル・ティスプレイ1991」日経BP社.

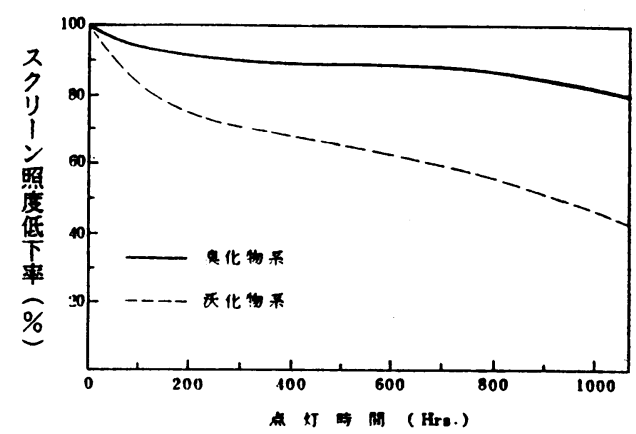

図 1 封入ハロゲン化物と程特性

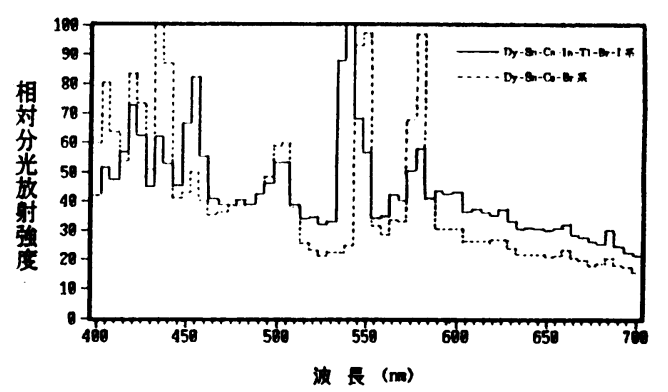

図2 液晶プロジェクタ用メタルハライドランプ の分光分布

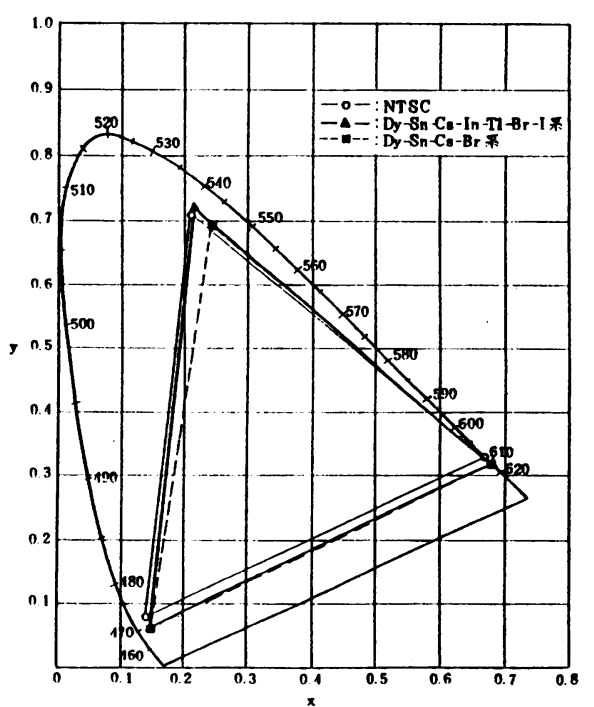

A study of metal halide lamp for projector II romichi Kawashima, Ichiro Tanaka, Kazuo Honda
因3波晶プロジェクタ用メタルハライドランプの色再現性 